\title{
Correlation-regression model for physico-chemical quality of groundwater in the South Indian city of Gulbarga
}

\author{
Abdul Saleem $^{1 *}$, Mallikarjun N. Dandigi ${ }^{2}$ and K. Vijay Kumar ${ }^{3}$ \\ ${ }^{1}$ Department of Civil Engineering, PDA College of Engineering, Gulbarga, India. \\ ${ }^{2}$ PDA College of Engineering, Gulbarga, India. \\ ${ }^{3}$ Department of Zoology, Gulbarga University Gulbarga, India.
}

Accepted 2 July, 2012

\begin{abstract}
Groundwater is a major source of municipal and private water supply in Gulbarga city. Water samples were collected from spatially referenced bore wells located in various wards of the city. 150 bore well water samples were analyzed for electrical conductivity (EC), $\mathrm{pH}$, total dissolved solids (TDS), total hardness (TH), $\mathrm{Ca}^{2+}, \mathrm{Mg}^{2+}, \mathrm{Na}^{+}, \mathrm{K}^{+}, \mathrm{HCO}_{3}{ }^{-}, \mathrm{CO}_{3}{ }^{2-} \mathrm{Cl}^{-}, \mathrm{SO}_{4}{ }^{2-}, \mathrm{NO}_{3}, \mathrm{~F}$ and $\mathrm{Fe}$. All tests were performed as per standard methods and water quality was compared for both Indian and WHO drinking water standards. Significantly positive correlation at 1 and $5 \%$ was found between many parameters. EC prediction with multiple $\mathrm{R}^{2}$ value of 0.999 indicated that $99.9 \%$ variability in observed EC could be ascribed to $\mathrm{Cl}^{-}(76 \%)$, $\mathrm{HCO}_{3}(12.5 \%), \mathrm{NO}_{3}^{-}(10.3 \%)$ and $\mathrm{SO}_{4}{ }^{2-}(1.1 \%)$. Multiple regression models can predict $\mathrm{EC}$ at $5 \%$ level of significance. Nitrate, chlorides, TDS and fluoride concentration exceed permissible level of drinking water in $75,41,95$ and $3.33 \%$ of the samples respectively. It is recommended to treat groundwater prior to domestic use.
\end{abstract}

Key words: Groundwater, water quality, bore well, water supply, correlation, regression.

\section{INTRODUCTION}

Groundwater is the prime source of drinking water supply for many of the Indian rural and urban habitats, like other parts of the world. Contamination of groundwater results in poor drinking water quality, high clean-up costs, high costs for alternative water supplies, and/or potential health problems. As worldwide extraction of groundwater is accelerated to meet increasing demand, the significance of chemical quality of groundwater also increases, relative to its economic value and usefulness (Adhikari et al., 2009). Optimal and sustainable usage of ground water is possible only when the quantity and quality is properly assessed. Rapid deterioration of groundwater quality is commonly observed in places which are densely populated, thickly industrialized and have shallow groundwater table (Patil et al., 2001).

\footnotetext{
*Corresponding author. E-mail: abdussaleem@yahoo.com. Tel: +97455841130.
}

Rasula and Rasula (2001) studied groundwater quality for Belgrade city, specifically for the zones of infrastructure facilities such as roads, railway, oil and gas pipelines, which may be considered as potential linear polluters. He concluded that with traffic development and economic growth, many potential groundwater sources would not be adequately exploited if hydro geological investigations are not undertaken in zones of infrastructure.

Urban groundwater in Seoul, South Korea, was monitored for trace metal and volatile organic compound and its relation to land use and spatial distribution. It is reported that some volatile organic compounds are significantly higher in the industrial, residential and traffic areas, suggesting that groundwater quality in urban areas is closely related with land use (Seong-Sook et al., 2005). Nitrate pollution increased dramatically between 1998 and 2001 in groundwater of Konya city in Turkey (Nas and Berktay, 2006).

Study on the impact of urbanization on the groundwater 
in Sholapur city in India (Pradeep et al., 2008) revealed a rise in groundwater level in the city area due to increased recharge associated with increased water supply; the water quality is reported to be deteriorating over the last 10 years. Subba Rao (2008) studied groundwater chemistry in parts of Guntur district in India, and reported higher concentration of total dissolved solids (TDS), $\mathrm{Na}^{+}$, $\mathrm{Mg}^{2+}, \mathrm{Cl}^{-}, \mathrm{SO}^{2-}, \mathrm{NO}_{3}^{-}, \mathrm{F}^{-}$and $\mathrm{SiO}_{2}$ ions in the groundwater during post-monsoon period. Groundwater regime of Varaha river basin study in Andhra Pradesh, India, showed that alkaline environment is the dominant controlling factor for leaching of fluoride from the source material in groundwater (Subba Rao, 2009). It is suggested that increasing effective infiltration through surface water management structures may reduce fluoride concentration in groundwater. Madhavi and Prasad (2003) observed that indiscriminate disposal of industrial effluent around Hyderabad has aggravated the acidity of electrical conductivity (EC), TDS, COD, $\mathrm{Cl}^{-}$, $\mathrm{SO}_{4}{ }^{2-}, \mathrm{PO}_{4}{ }^{2-}, \mathrm{NO}_{3}^{-}, \mathrm{F}^{-}$and heavy metals in the groundwater.

Mohapatra et al. (2001) made a correlation study on the physico-chemical characteristics of groundwater in Paradip areas. Statistical calculations were made to interpret the quality of groundwater of seven villages around Udayarpalayam, Tamil Nadu (Sangeetha et al., 2000). The reliability between well water and bore well water was predicted from the values of co-efficient of variance in correlation co-efficient. Ground water quality of an industrial town, Bhilwara, in Rajasthan, showed (Sharma et al., 2001) a positive correlation among total hardness $(\mathrm{TH})$ and $\mathrm{EC}$ with $\mathrm{Mg}^{+}$and TDS. Linear relation was obtained for rapid monitoring of groundwater alkalinity. The experimental values of $\mathrm{Cl}^{-}$and TDS agreed with predicted values calculated as function of EC.

Considering the huge groundwater consumption in Gulbarga city and lack of water quality monitoring, the present study is undertaken. The main objective of the study is to assess the quality of groundwater based on large number of spatially referenced sampling wells located in various wards of the city. An attempt is made to represent water quality through conventional physicochemical parameters. Suitability of groundwater for drinking and irrigation purposes is explored. Statistical analysis and characterization of hydro geochemistry of the ground water, with correlation and regression model is also presented.

\section{Study area}

Gulbarga (Figure 1) is a major city in the south Indian state of Karnataka. It lies geographically between latitudes $17^{\circ} 17^{\prime}$ to $17^{\circ} 22^{\prime}$ and longitudes $76^{\circ} 47^{\prime}$ to $76^{\circ} 52^{\prime}$, at a mean sea level of $454 \mathrm{~m}$. It covers an area of 54.13 $\mathrm{km}^{2}$, with a population of 430,000 and over 50,000 properties as per census record of the year 2001. It is divided into 55 corporation wards based on population and municipal jurisdiction. Average annual rainfall observed is about $750 \mathrm{~mm}$ and the mean daily temperatures range from $19^{\circ} \mathrm{C}$ in winter to over $40^{\circ} \mathrm{C}$ in summer. The study area is identified as a chronically drought prone district of the Karnataka state, due to less and variable occurrence of annual rainfall. The district is underlain by the Deccan traps of upper Cretaceous to Eocene age. Groundwater occurs in the deeper weathered and fractured zones. It occurs in water table condition in weathered zone and in semi confined conditions in the fractured and joined formations. The depth of the wells ranges between 20 and $30 \mathrm{~m}$ (Majagi et al., 2008).

Gulbarga city is served by piped potable water supply derived from Bennithora and Bhima rivers and Bhosga reservoir located 10 to $25 \mathrm{~km}$ away from the city and through more than 1850 bore wells installed and maintained by City Corporation. Two million gallons per day of groundwater is supplied by the city corporation which constitute about $30 \%$ of daily water supply to the city (Gulbarga city, 2010). Apart from municipal bore wells, groundwater is also extracted from large number of private bore wells. There is no record of the number of private bore wells in the city. Based on physical observation, it may be safely quoted that almost every third house has one bore well and the total number of bore wells in the city may exceed 20,000. The municipality water supply extracted from the bore wells without any treatment and most of the private bore well users also consume groundwater without treatment (Saleem et al., 2011).

\section{MATERIALS AND METHODS}

\section{Groundwater sampling and analysis}

Groundwater samples were collected in clean plastic containers of $2 \mathrm{~L}$ capacity during March 2009 from 150 bore wells, spread in all 55 municipal wards of the city. The selected bore wells are both municipal and private owned and were fitted with either hand pump or electric motor and were being used to supply water for domestic demand. Water of the bore well was run for 2 to $3 \mathrm{~min}$ and the containers were rinsed with the sample water prior to collection of the sample.

The samples were immediately transferred to the laboratory and analyzed for various physico-chemical parameters, namely, EC, $\mathrm{TH}, \mathrm{Ca}^{2+}, \mathrm{Mg}^{2+}, \mathrm{Na}^{+}, \mathrm{K}^{+}, \mathrm{HCO}_{3}^{-}, \mathrm{Cl}^{-}, \mathrm{SO}_{4}{ }^{2-}, \mathrm{NO}_{3}{ }^{-}, \mathrm{F}$ and $\mathrm{Fe}$, using standard methods (APHA, 1989). The analyzed test results were checked for electro-neutrality and the percentage difference of cation and anion was found to be within the acceptable range of $5 \%$. Mean, standard deviation, correlation and regression were calculated using SPSS software.

\section{RESULTS AND DISCUSSION}

The minimum, maximum, mean and standard deviation 


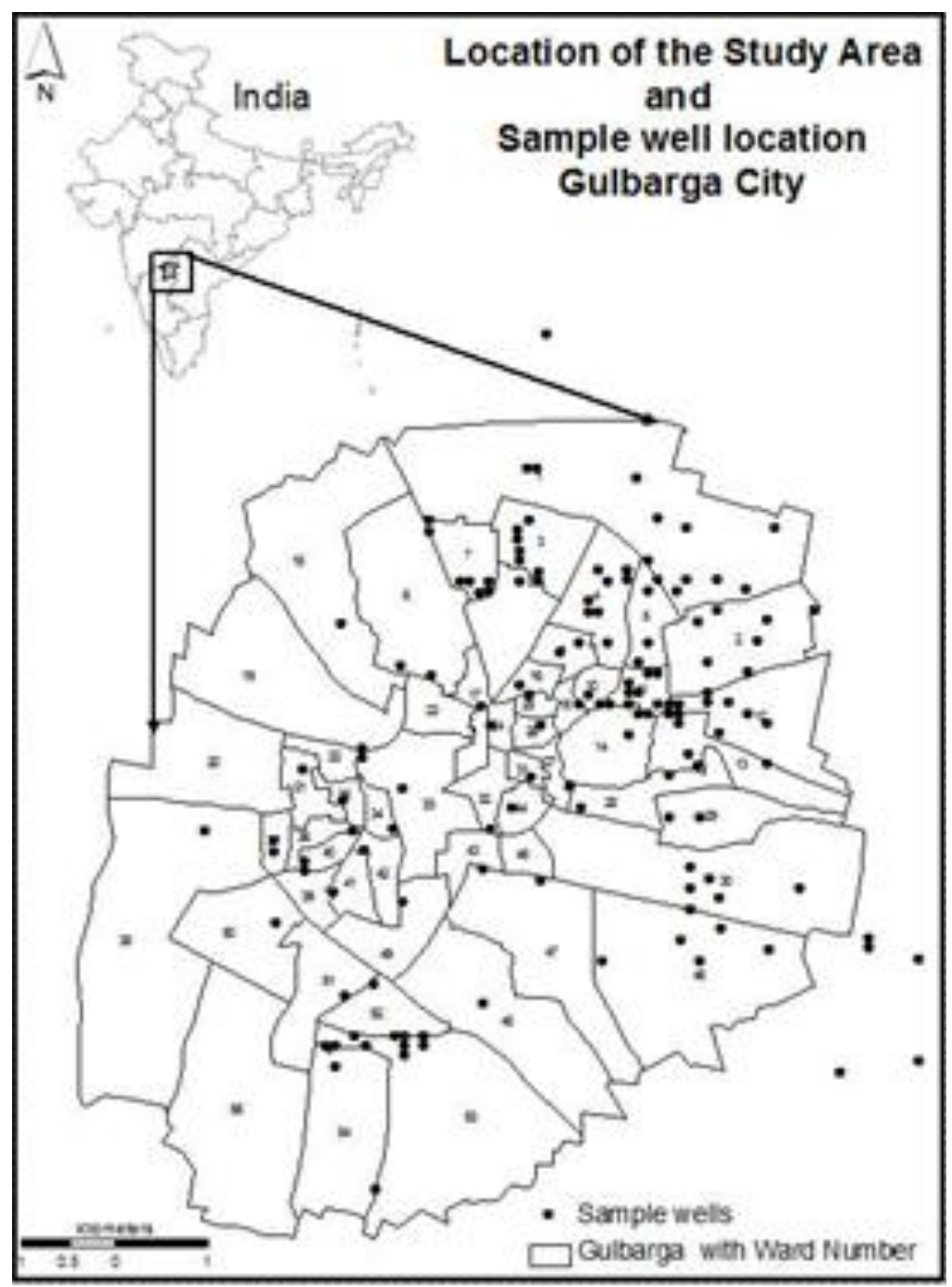

Figure 1. Spatial position of sampling bore wells.

values generated from the analysis of the 150 samples are presented in Table 1. The data was compared with drinking water guidelines of India (ISI, 1991) and WHO (1993), and tabulated in Table 2. It was observed that $\mathrm{pH}$ of ground water is between 6.8 and 8.40 and meets drinking water criteria. Among the cations, calcium dominates, ranging between 16 and $429 \mathrm{mg} / \mathrm{L}$, and mean of $112.42 \mathrm{mg} / \mathrm{L}$. About $67.5 \%$ of samples observed with $\mathrm{Ca}^{2+}$ value are more than the desirable limit of $75 \mathrm{mg} / \mathrm{L}$; however, excess $\mathrm{Ca}^{2+}$ is not a hazard as $90 \%$ of the samples showed value below $200 \mathrm{mg} / \mathrm{L}$, the maximum permissible limit. Magnesium varies between 3 and 193 $\mathrm{mg} / \mathrm{L}$ with $95 \%$ samples within maximum permissible value of $100 \mathrm{mg} / \mathrm{L}$. Potassium values ranged between 1 and $20 \mathrm{ppm} \mathrm{mg/L}$, with $97 \%$ samples conforming to UK (max) limit of $12 \mathrm{mg} / \mathrm{L}$.

In terms of salinity hazard (Table 6), 98\% water samples indicated high /very high salinity values. The maximum contaminant level (MCL) for chloride in drinking water is $250 \mathrm{mg} / \mathrm{L}$ as per WHO and Indian standards. In the present study, chloride concentration varied from 64 to $784 \mathrm{mg} / \mathrm{L}$, with mean value of $249.4 \mathrm{mg} / \mathrm{L}$, and standard deviation of $112.5 \mathrm{mg} / \mathrm{L}$. About $58.7 \%$ of samples fall within the maximum chloride limit of 250 $\mathrm{mg} / \mathrm{L}$. Shanthi et al. (2002) reported that higher concentration of chloride is an indicator of pollution due to higher animal waste. Sivakumar et al. (2000) and Haran (2002) reported that chloride concentration up to 250 $\mathrm{mg} / \mathrm{L}$ are not harmful but is an indication of organic pollution resulting from sewage mixing and increased temperature and evapo-transpiration of water.

Maximum permissible limit for nitrate in drinking water is $50 \mathrm{mg} / \mathrm{L}$ as per $\mathrm{WHO}$ and $45 \mathrm{mg} / \mathrm{L}$ as per Indian standards. In the present study, nitrate varied from 9 to $680 \mathrm{mg} / \mathrm{L}$ with mean and SD of 102.2, and 99.18, respectively. About $75.3 \%$ of the samples exceed nitrate concentration permissible level of $45 \mathrm{mg} / \mathrm{L}$. Majagi et al. (2008) also reported excess nitrate level of $342 \mathrm{mg} / \mathrm{L}$ in 
Table 1. Groundwater physic chemical quality descriptive statistics.

\begin{tabular}{lcccc}
\hline Parameter & Minimum & Maximum & Mean & Std. Deviation \\
\hline $\mathrm{pH}$ & 6.80 & 8.40 & 7.83 & 0.39 \\
$\mathrm{EC}$ & 575.00 & 3220.00 & 1571.47 & 510.04 \\
$\mathrm{TDS}$ & 82.00 & 1910.00 & 926.43 & 313.41 \\
$\mathrm{TH}$ & 52.00 & 1184.00 & 459.04 & 229.73 \\
$\mathrm{Ca}^{2+}$ & 16.00 & 429.00 & 112.83 & 67.25 \\
$\mathrm{Mg}^{2+}$ & 3.00 & 193.00 & 44.26 & 32.48 \\
$\mathrm{Na}^{+}$ & 26.00 & 360.00 & 145.84 & 64.94 \\
$\mathrm{~K}^{+}$ & 1.00 & 20.00 & 5.15 & 3.81 \\
$\mathrm{HCO}_{3}{ }^{-}$ & 98.00 & 652.00 & 275.15 & 96.25 \\
$\mathrm{CO}_{3}{ }^{-2}$ & 0 & 0 & 0 & 0 \\
$\mathrm{Cl}^{-}$ & 64.00 & 784.00 & 249.44 & 112.47 \\
$\mathrm{SO}_{4}{ }^{2-}$ & 29.00 & 220.00 & 122.53 & 38.68 \\
$\mathrm{NO}_{3}{ }^{-}$ & 9.00 & 680.00 & 102.22 & 99.18 \\
$\% \mathrm{Na}^{-}$ & 8.12 & 89.23 & 42.50 & 17.23 \\
$\mathrm{~F}$ & 0.05 & 0.9 & 0.253 & 0.372 \\
$\mathrm{Fe}^{-12}$ & 0.1 & 8.87 & 0.1037 & 0.013 \\
$\mathrm{SAR}^{2+}$ & 0.35 & 457.00 & 2.63 & 1.57 \\
$\mathrm{Na}^{+}+\mathrm{Mg}^{2+}$ & 19.00 & 370.00 & 156.82 & 79.41 \\
$\mathrm{Ca}^{2+}+\mathrm{Mg}^{2+} / \mathrm{Na}^{+}+\mathrm{K}^{+}$ & 28.00 & 8.00 & 150.68 & 67.64 \\
\hline
\end{tabular}

$\mathrm{N}=150$. All the values are in $\mathrm{mg} / \mathrm{L}$ except $\mathrm{EC}$, in $\mu \mathrm{S} / \mathrm{cm}$.

Gulbarga city during 2001 to 2002 , and attributed this to poor sewerage and solid waste disposal system, leaky sewers, large number of septic tanks and soak pits, and practice of sewage discharge through open surface drains. High incidence of water related diseases such as cholera, jaundice, typhoid and diarrhoea were reported for Gulbarga city due to non wholesome water supply, poor sanitation and inefficient solid waste collection and disposal system (Degaonkar and Chaya, 2003). The problem of groundwater contamination by nitrates has been thoroughly studied all over the world and has been found that water in shallow wells containing more than 45 $\mathrm{mg} / \mathrm{L}$ excess nitrate content causes methemoglobinemia/blue baby syndrome in humans (Durfor and Baker, 1964). Several studies document adverse effects of higher nitrate levels, most notably methemoglobinemia (Hudak, 2000; Levallois et al., 1998; WHO, 1985).

Total dissolved solids values indicate that $95 \%$ of the water samples (142 bore wells) were above the desirable limit of $500 \mathrm{mg} / \mathrm{L}$ and TDS ranged between 82 and 1910 $\mathrm{mg} / \mathrm{L}$ with mean and SD of 926 and 313, respectively. Groundwater classification based on TDS values is presented in Tables 3 and 4 . The results indicated fresh water type for $62.7 \%$ of the sample locations and the rest represent brackish water based on Freeze and Cherry (1979). As per Davis and Dewiest (1966) classification method, only $5.3 \%$ of the samples (8 bore wells) have TDS below $500 \mathrm{mg} / \mathrm{L}$. Almost all the samples need to be treated before supply. TDS concentration was high due to the presence of bicarbonates, carbonates, sulphates and chlorides of calcium (Subba Rao et al., 1998; Deepali et al., 2001) and TDS value of $500 \mathrm{mg} / \mathrm{L}$ is the desirable limit and water containing more than $500 \mathrm{mg} / \mathrm{L}$ TDS causes gastrointestinal irritation (Jain et al., 2003). High value of TDS influences the taste, hardness, and corrosive property of the water (Joseph and Jaiprakash, 2000; Haran, 2002; Subhadra Devi et al., 2003).

Groundwater classification based on hardness value is given in Table 5. Hardness values ranged from 52 to $1184 \mathrm{mg} / \mathrm{L}$ with mean and SD of 459 and 229, respectively. The maximum allowable limit of $\mathrm{TH}$ for drinking purpose is $600 \mathrm{mg} / \mathrm{L}$ and the desirable limit is $300 \mathrm{mg} / \mathrm{L}$ (ISI, 1991). Groundwater exceeding the limit of $300 \mathrm{mg} / \mathrm{L}$ is considered to be very hard (Sawyer and McCarty, 1967). TDS in $71.3 \%$ of groundwater samples (107 bore wells) exceed the maximum allowable limit of $500 \mathrm{mg} / \mathrm{L}$. All the groundwater samples were rated as hard to very hard and require softening prior to domestic uses.

Fluoride varies from 0.05 to $1.9 \mathrm{mg} / \mathrm{L}$, with mean value $0.253 \mathrm{mg} / \mathrm{L}$ and SD of $0.372 \mathrm{mg} / \mathrm{L}$. Five samples exceed permissible limit of $1.5 \mathrm{mg} / \mathrm{L}$. Excess fluoride are also reported in the outskirts of the city (The Hindu, 2011) and in some villages $30 \mathrm{~km}$ from the city (Shivashankara et al., 2000). Iron content in the groundwater was observed within the permissible limit of drinking water and ranged between 0.05 and $0.10 \mathrm{mg} / \mathrm{L}$, with a mean of $0.1037 \mathrm{mg} / \mathrm{L}$ 
Table 2. Comparison of the samples bore well water with drinking water standards.

\begin{tabular}{|c|c|c|c|c|c|}
\hline \multirow[b]{2}{*}{$\begin{array}{l}\text { Substance } \\
\text { characteristic }\end{array}$} & \multicolumn{2}{|c|}{ IS $10500: 1991$} & \multirow{2}{*}{$\begin{array}{l}\text { WHO (1993) } \\
\text { recommendation }\end{array}$} & \multirow[b]{2}{*}{ Undesirable effect outside the desirable limit } & \multirow{2}{*}{$\begin{array}{l}\% \text { Sample exceeding recommended } \\
\text { value }\end{array}$} \\
\hline & $\begin{array}{c}\text { Desirable } \\
\text { limit }\end{array}$ & $\begin{array}{l}\text { Permissible } \\
\text { limit }\end{array}$ & & & \\
\hline \multicolumn{6}{|c|}{ Essential characteristics } \\
\hline $\mathrm{pH}$ value & 6.5 to 8.5 & No relaxation & $<8.0$ & $\begin{array}{l}\text { Beyond this range the water will affect the } \\
\text { mucous membrane and/or water supply system }\end{array}$ & $100 \%$ within range of $6.5-8.5$ \\
\hline $\begin{array}{l}\text { Total hardness (as } \\
\left.\mathrm{CaCO}_{3}\right) \mathrm{mg} / \mathrm{L}\end{array}$ & 300 & 600 & & $\begin{array}{l}\text { Encrustation in water supply structure and } \\
\text { adverse effects on domestic use }\end{array}$ & $\begin{array}{l}71.3 \% \text { above } 300 \text {, and } 23.3 \% \text { above } 600 \\
\mathrm{mg} / \mathrm{L}\end{array}$ \\
\hline $\mathrm{Cl}^{-} \mathrm{mg} / \mathrm{lL}$ & 250 & 1000 & 250 & $\begin{array}{l}\text { Beyond this limit, taste, corrosion and } \\
\text { palatability are affected }\end{array}$ & $\begin{array}{l}58.7 \% \text { below and } 41.3 \% \text { exceeds } 250 \\
\mathrm{mg} / \mathrm{L}\end{array}$ \\
\hline \multicolumn{6}{|c|}{ Desirable characteristics } \\
\hline $\begin{array}{l}\text { Dissolved solids } \\
\text { (TDS) } \mathrm{mg} / \mathrm{L}\end{array}$ & 500 & 2000 & 1000 & $\begin{array}{l}\text { Beyond this palatability decreases and may } \\
\text { cause gastro intestinal irritation }\end{array}$ & $\begin{array}{l}5.3 \% \text { below } 500.58 .7 \text { between } 500- \\
1000,36 \% \text { above } 1000 \mathrm{mg} / \mathrm{L}\end{array}$ \\
\hline $\mathrm{Ca}^{2+} \mathrm{mg} / \mathrm{L}$ & 75 & 200 & 250 (UK 1989 max) & $\begin{array}{l}\text { Encrustation in water supply structure and } \\
\text { adverse effects on domestic use }\end{array}$ & $\begin{array}{l}32 \% \text { below } 75,58.7 \% \text { between } 75-200 \text {, } \\
9.3 \% \text { above } 200 \mathrm{mg} / \mathrm{L}\end{array}$ \\
\hline $\mathrm{Mg}^{2+} \mathrm{mg} / \mathrm{L}$ & 30 & 100 & 50 (UK 1989 max) & $\begin{array}{l}\text { Encrustation in water supply structure and } \\
\text { adverse effects on domestic use }\end{array}$ & $\begin{array}{l}39.3 \%<30,60.6 \%<50,94.6 \%<100, \\
5.4 \%<100 \mathrm{mg} /\end{array}$ \\
\hline $\mathrm{Na}^{+} \mathrm{mg} / \mathrm{L}$ & & & 200 & & $78.7 \%$ below, $21.3 \%$ above $200 \mathrm{mg} / \mathrm{L}$ \\
\hline $\mathrm{K}^{+} \mathrm{mg} / \mathrm{L}$ & & & 12 (UK 1989 max) & & $93.3 \%<12,6.7 \%>12 \mathrm{mg} / \mathrm{L}$ \\
\hline $\mathrm{SO}_{4}^{2}-\mathrm{mg} / \mathrm{L}$ & 200 & 400 & 250 & $\begin{array}{l}\text { causes gastro intestinal irritation when } \mathrm{Mg} \text { or } \mathrm{Na} \\
\text { are present }\end{array}$ & $\begin{array}{l}96 \% \text { below } 200 \text { and } 4 \% \text { between } 200- \\
400 \mathrm{mg} / \mathrm{L}\end{array}$ \\
\hline $\mathrm{NO}_{3}^{-} \mathrm{mg} / \mathrm{L}$ & 45 & 100 & 50 & Methemoglobinemia takes place & $\begin{array}{l}24.7 \%<45,30 \%<50,43 \% \text { between } 45- \\
100,32.7 \% \text { above } 100 \mathrm{mg} / \mathrm{L}\end{array}$ \\
\hline $\mathrm{HCO}_{3}^{-}(\mathrm{mg} / \mathrm{L})$ & 200 & 600 & & Beyond this limit taste becomes unpleasant & $74.7 \%$ above $200 \mathrm{mg} / \mathrm{L}$ \\
\hline $\mathrm{F}(\mathrm{mg} / \mathrm{L})$ & 1 & 1.5 & 1.5 & High fluoride may causes fluorosis & $\begin{array}{l}10 \% \text { exceed } 1.5 \mathrm{mg} / \mathrm{L}, \text { max value is } 1.9 \\
\mathrm{mg} / \mathrm{L}\end{array}$ \\
\hline $\mathrm{Fe}(\mathrm{mg} / \mathrm{l})$ & 0.3 & 1 & 0.3 & $\begin{array}{l}\text { Taste/appearance are affected, has adverse } \\
\text { effect on domestic uses and water supply } \\
\text { structures }\end{array}$ & All samples show Fe within the limit \\
\hline
\end{tabular}


Table 3. Classification of water based on TDS by Davis and DeWiest (1966).

\begin{tabular}{llcc}
\hline TDS $\mathbf{( m g / L )}$ & Class & No. of samples & \% of samples \\
\hline$<500$ & Desirable for drinking & 8 & 5.3 \\
$500-1000$ & Permissible for drinking & 88 & 58.7 \\
$1000-3000$ & Useful for irrigation & 54 & 36 \\
$>3000$ & Unfit for drinking and irrigation & 0 & 0 \\
Total & & 150 & 100 \\
\hline
\end{tabular}

Table 4. Classification of water based on TDS by Freeze and Cherry (1979).

\begin{tabular}{llcc}
\hline TDS $\mathbf{( m g / L )}$ & Class & No. of samples & \% of samples \\
\hline$<1000$ & Fresh water type & 94 & 62.7 \\
$1000-10000$ & Brackish water type & 56 & 37.3 \\
$10000-100000$ & Saline water type & 0 & 0 \\
$>100000$ & Brine water type & 0 & 0 \\
Total & & 150 & 100 \\
\hline
\end{tabular}

Table 5. Classification of water based on hardness (Sawyer and McCarty, 1967).

\begin{tabular}{llcc}
\hline TH $(\mathbf{m g} / \mathbf{L})$ & Water type & No. of samples & \% of samples \\
\hline $0-75$ & Soft & 1 & 0.7 \\
$75-150$ & Moderately hard & 5 & 3.3 \\
$150-300$ & Hard & 37 & 24.7 \\
$>300$ & Very hard & 107 & 71.3 \\
Total & & 150 & 100 \\
\hline
\end{tabular}

Table 6. Classification of water samples after US salinity laboratory staff (1954).

\begin{tabular}{lccc}
\hline Salinity hazard & $\mathbf{E C}$ (micromohs $\mathbf{c m}$ ) at $\mathbf{2 5 ^ { \circ } \mathbf { C }}$ & No. of samples & \% of samples \\
\hline Low & $<250$ & 0 & 0 \\
Medium & $250-750$ & 3 & 2 \\
High & $750-2250$ & 133 & 88.7 \\
Very high & $>2250$ & 14 & 9.3 \\
Total & & 150 & 100 \\
\hline
\end{tabular}

and SD of $0.013 \mathrm{mg} / \mathrm{L}$, respectively. EC values varied between 575 and $3220 \mu \mathrm{S} / \mathrm{cm}$, with mean and SD of 1571 and 510, respectively, and showed a salinity hazard from high to very high as shown in Table 6 .

Sodium concentration is one of the important parameters in the classification of irrigation water. Soils containing a large proportion of sodium with carbonate as predominant anion are termed alkali soils and those with chloride or sulphate as predominant anion are termed as saline soils and these affects plant growth (Todd, 2007). Sodium content is usually expressed in terms of percent sodium defined by:

$\% \mathrm{Na}=\left(\mathrm{Na}^{+}+\mathrm{K}^{+}\right)^{*} 100 /\left(\mathrm{Ca}^{2+}+\mathrm{Mg}^{2+}+\mathrm{Na}^{+}+\mathrm{K}^{+}\right.$ where all ionic concentrations are expressed in milli equivalents per litre. Percent sodium classification is presented in Table 7, which indicates that most of the water is suitable for irrigation purposes. The salinity laboratory of USDA recommends sodium adsorption ratio (SAR) due to its direct relation to adsorption of sodium by soil and is defined by:

$$
S A R=N a \div \sqrt{((C a+M g)} / 2)
$$

where all ionic concentrations are expressed in milli equivalents per litre. Classification of the analyzed water for irrigation, based on SAR and EC indicated a low sodium alkali hazard and high to very high salinity hazard 
Table 7. Groundwater classification according to \%Na (Wilcox, 1955).

\begin{tabular}{clcc}
\hline Na $(\%)$ & Class & No. of sample & \% of samples \\
\hline $0-20$ & Excellent & 14 & 9.3 \\
$20-40$ & Good & 60 & 40 \\
$40-60$ & Permissible & 49 & 32.7 \\
$60-80$ & Doubtful & 25 & 16.7 \\
$>80$ & Unsuitable & 2 & 1.3 \\
Total & & 150 & 100 \\
\hline
\end{tabular}

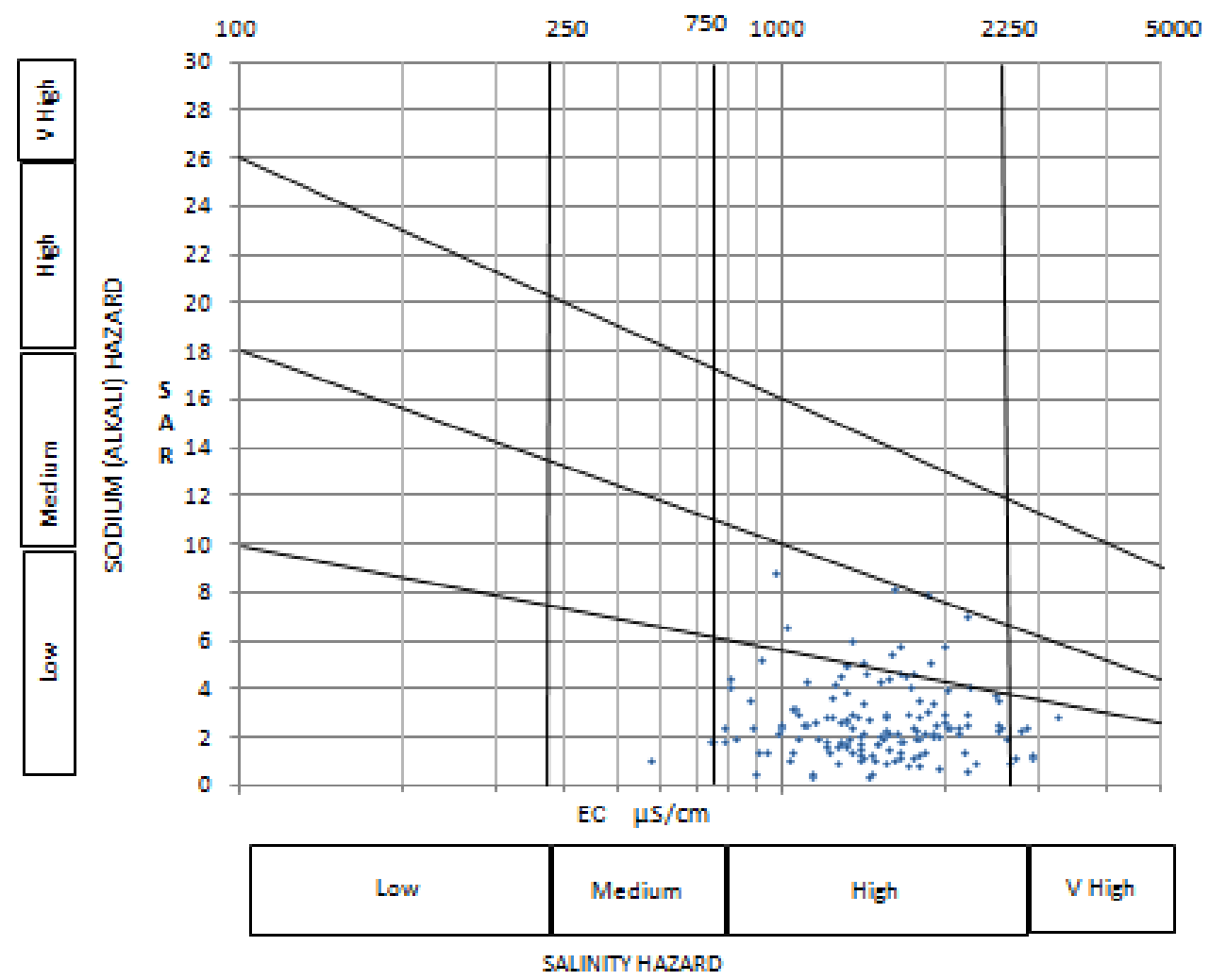

Figure 2. Classification of groundwater for irrigation (after Richard's).

in the collected groundwater samples (Figure 2).

Groundwater type is also shown through piper diagram as in Figure 3. It indicates that the sampled groundwater is characterized by prevalence of calicum, magnesium and sodium cations and sulfate and chlorides anions.

\section{Normal statistics for variables}

\section{Correlation analysis}

Correlation and regression analysis is useful for interpreting groundwater quality data and relating them to specific hydro geological processes. These tools are quite useful in characterizing and obtaining first hand information of the groundwater system than actually going through complex methods and procedures. Table 1 presents the range, arithmetic mean and standard deviation for the cations and anions considered, and transformations used in the multiple regression analysis. The range, mean and standard deviation values revealed considerable variations in the water samples with respect to their chemical composition.

The degree of linear association between any two of the water quality parameters is measured by the simple correlation coefficient (r). Correlation matrix for different water quality parameters along with the significance level (2 tailed) is shown in Table 8. It is observed that the significant correlation between EC and other hydro geochemical parameters is significantly positive. 


\section{Piper diagram for Groundwater of Gulbarga from 150 bore wells}

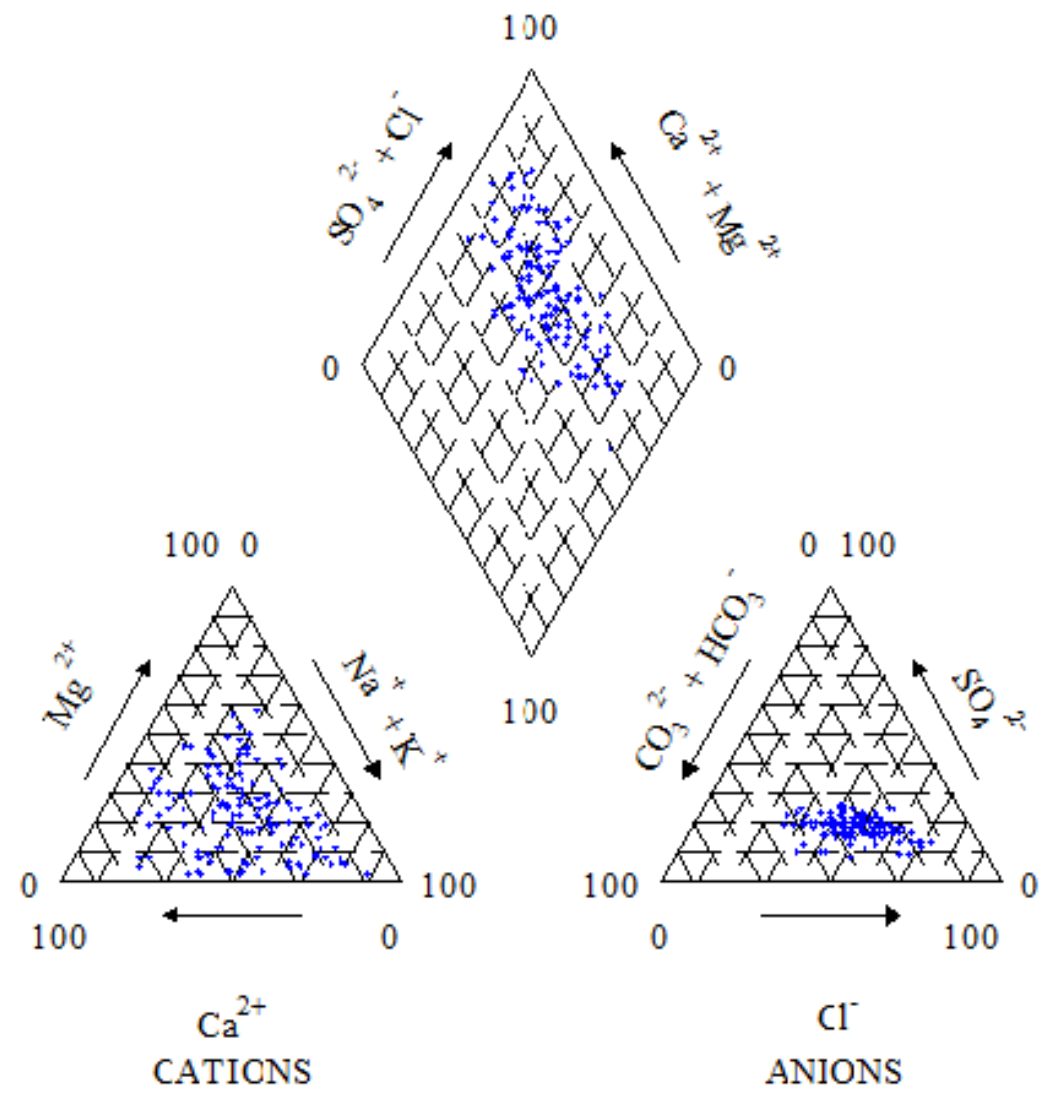

Figure 3. Piper diagram reflecting groundwater type.

The $r$ value between $\mathrm{EC}$ and $\mathrm{Ca}^{2+}$ and $\mathrm{Mg}^{2+}$ was 0.814 and for $\mathrm{Na}^{+}+\mathrm{K}^{+}$, it was 0.434 and the relative coefficient of determined value shows that the 66.2 and $19 \%$ of the variability with $\mathrm{EC}$ could be respectively ascribed to the variable $\mathrm{Ca}^{2+}+\mathrm{Mg}^{2+}$ and $\mathrm{Na}^{+}+\mathrm{K}^{+}$concentration in the water. The correlation between $\mathrm{EC}$ and $\mathrm{Cl}^{-}$is significant $(r=0.872)$ and coefficient of determination value indicated that $76 \%$ of the variability in EC could be ascribed to the $\mathrm{Cl}$ concentration in water. $\mathrm{Ca}^{2+}(\mathrm{r}=$ $0.689), \mathrm{Mg}^{2+}(r=0.569), \mathrm{K}^{+}(r=0.568), \mathrm{HCO}_{3}^{-}(r=$ $0.594)$, and $\mathrm{SO}_{4}{ }^{2-}(r=0.783)$ are other significant variables with determined values for EC prediction.

Adhikari et al. (2009) studied statistical approaches for hydro geochemical characterization of groundwater in west Delhi, India. The study showed good correlation between EC and other water quality parameters and also showed that multiple regression model can predict EC at $5 \%$ level of significance.

\section{Regression analysis}

Multiple linear regression model was performed by using
SPSS software. Most multiple linear regression model in predicting $\mathrm{EC}$, TDS, $\mathrm{TH}, \mathrm{Ca}^{2+}+\mathrm{Mg}^{2+} \mathrm{Na}^{+}+\mathrm{K}^{+}, \mathrm{HCO}_{3}{ }^{-} \mathrm{Cl}^{-}$, $\mathrm{NO}_{3}{ }^{-}$and $\mathrm{SO}_{4}{ }^{2-}$ are presented in Table 9.

All the independent variables were noticed to have a significant effect (' $\mathrm{t}$ ' test for the partial regression coefficients at $5 \%$ level of probability) on the corresponding dependent variable. The prediction of EC from selected ionic compositions was fairly good. The independent variables such as $\mathrm{Cl}^{-}, \mathrm{HCO}_{3}{ }^{-}, \mathrm{NO}_{3}$ and $\mathrm{SO}_{4}$ were significant in predicting EC value. The multiple $R^{2}$ value $(0.999)$ indicates that $99.9 \%$ of the variability in EC could be ascribed to the combined effect of $\mathrm{Cl}^{-}, \mathrm{HCO}_{3}$, $\mathrm{NO}_{3}{ }^{-}$and $\mathrm{SO}_{4}{ }^{-}$.

Out of $99.9 \%$ of the variability in $\mathrm{EC}$ due to the combined effect of $\mathrm{Cl}^{-}, \mathrm{HCO}_{3}{ }^{-}, \mathrm{NO}_{3}{ }^{-}$and $\mathrm{SO}_{4}{ }^{2-}, 76 \%$ was due to $\mathrm{Cl}^{-}$alone and $12.5,10.3$ and $1.1 \%$ were due to $\mathrm{HCO}_{3}{ }^{-} \mathrm{NO}_{3}^{-}$and $\mathrm{SO}_{4}{ }^{2-}$ respectively (Table 10 ). $71.7 \%$ of the variability of $\mathrm{HCO}_{3}$ could be ascribed to the combined effect of $\mathrm{Na}^{+}, \mathrm{K}^{+}, \mathrm{Ca}^{2+}, \mathrm{Mg}^{2+}, \mathrm{Cl}^{-}$, and $\mathrm{SO}_{4}{ }^{2-}$ whereas in $\mathrm{Cl}^{-}, 89.6 \%$ of the variability of the observed $\mathrm{Cl}^{-}$ could be ascribed to the combined effect of $\mathrm{Na}^{+}, \mathrm{K}^{+}, \mathrm{Ca}^{++}$, $\mathrm{Mg}^{2+}, \mathrm{HCO}_{3}{ }^{-}, \mathrm{SO}_{4}{ }^{2-}$ and $\mathrm{NO}_{3}^{-}$. In predicting $\mathrm{NO}_{3}^{-}, 73.3 \%$ of the variability could be ascribed to the combined effect 
Table 8. Correlation matrix of water quality parameters with Sig level 2 - tailed.

\begin{tabular}{|c|c|c|c|c|c|c|c|c|c|c|c|c|c|c|c|}
\hline Parameter & EC & TDS & TH & $\mathrm{Na}^{+}$ & $\mathrm{K}^{+}$ & $\mathrm{Ca}^{++}$ & $\mathrm{Mg}^{++}$ & $\mathrm{HCO}_{3}{ }^{--}$ & $\mathrm{Cl}^{-}$ & $\mathrm{SO}_{4}^{--}$ & $\mathrm{NO}_{3}{ }^{-}$ & $\mathrm{Na}^{+}+\mathrm{K}^{+}$ & $\begin{array}{l}\mathrm{Ca}^{++} \\
\mathrm{Mg}^{++} \\
\end{array}$ & + & $\begin{array}{l}\mathrm{Ca}^{++}+\mathrm{Mg}^{++} / \\
\mathrm{Na}^{+}+\mathrm{K}^{+}\end{array}$ \\
\hline EC & 1 & & & & & & & & & & & & & & \\
\hline \multirow{2}{*}{ TDS } & $0.958^{* *}$ & 1 & & & & & & & & & & & & & \\
\hline & 0.000 & & & & & & & & & & & & & & \\
\hline \multirow{2}{*}{ TH } & $0.827^{* *}$ & $0.761^{* *}$ & 1 & & & & & & & & & & & & \\
\hline & 0.000 & 0.000 & & & & & & & & & & & & & \\
\hline \multirow{2}{*}{$\mathrm{Na}^{+}$} & $0.419^{\star *}$ & $0.454^{\star \star}$ & $-0.163^{\star}$ & 1 & & & & & & & & & & & \\
\hline & 0.000 & 0.000 & 0.047 & & & & & & & & & & & & \\
\hline \multirow{2}{*}{$\mathrm{K}^{+}$} & $0.568^{* *}$ & $0.567^{\star *}$ & 0.156 & $0.726^{* \star}$ & 1 & & & & & & & & & & \\
\hline & 0.000 & 0.000 & 0.056 & 0.000 & & & & & & & & & & & \\
\hline \multirow{2}{*}{$\mathrm{Ca}^{++}$} & $0.689^{* *}$ & $0.684^{* *}$ & $0.830^{\star *}$ & -0.119 & 0.079 & 1 & & & & & & & & & \\
\hline & 0.000 & 0.000 & 0.000 & 0.147 & 0.335 & & & & & & & & & & \\
\hline \multirow{2}{*}{$\mathrm{Mg}^{++}$} & $0.569^{* *}$ & $0.460^{* *}$ & $0.693^{\star *}$ & -0.134 & $0.173^{\star}$ & $0.174^{\star}$ & 1 & & & & & & & & \\
\hline & 0.000 & 0.000 & 0.000 & 0.102 & 0.034 & 0.033 & & & & & & & & & \\
\hline \multirow{2}{*}{$\mathrm{HCO}_{3}$} & $0.594^{* \star}$ & $0.547^{\star *}$ & $0.464^{* *}$ & $0.287^{\star *}$ & $0.527^{\star *}$ & $0.305^{\star \star}$ & $0.426^{\star *}$ & 1 & & & & & & & \\
\hline & 0.000 & 0.000 & 0.000 & 0.000 & 0.000 & 0.000 & 0.000 & & & & & & & & \\
\hline \multirow{2}{*}{$\mathrm{Cl}^{-}$} & $0.872^{\star \star}$ & $0.811^{* *}$ & $0.707^{\star \star}$ & $0.387^{\star \star}$ & $0.481^{\star *}$ & $0.490^{\star \star}$ & $0.616^{\star \star}$ & $0.294^{\star *}$ & 1 & & & & & & \\
\hline & 0.000 & 0.000 & 0.000 & 0.000 & 0.000 & 0.000 & 0.000 & 0.000 & & & & & & & \\
\hline \multirow{2}{*}{$\mathrm{SO}_{4}{ }^{2-}$} & $0.783^{\star *}$ & $0.752^{\star \star}$ & $0.585^{\star \star}$ & $0.429^{* *}$ & $0.500^{\star \star}$ & $0.491^{* *}$ & $0.399^{\star *}$ & $0.573^{\star *}$ & $0.631^{* *}$ & 1 & & & & & \\
\hline & 0.000 & 0.000 & 0.000 & 0.000 & 0.000 & 0.000 & 0.000 & 0.000 & 0.000 & & & & & & \\
\hline \multirow{2}{*}{$\mathrm{NO}_{3}^{-}$} & $0.470^{* *}$ & $0.521^{* *}$ & $0.474^{* *}$ & 0.070 & 0.080 & $0.671^{* *}$ & -0.030 & 0.041 & $0.182^{*}$ & $0.174^{*}$ & 1 & & & & \\
\hline & 0.000 & 0.000 & 0.000 & 0.392 & 0.333 & 0.000 & 0.714 & 0.620 & 0.026 & 0.033 & & & & & \\
\hline \multirow{2}{*}{$\mathrm{Na}^{+}+\mathrm{K}^{+}$} & $0.434^{* *}$ & $0.467^{\star *}$ & -0.147 & $0.999^{\star *}$ & $0.752^{* *}$ & -0.110 & -0.119 & $0.305^{\star *}$ & $0.398^{* *}$ & $0.439^{* *}$ & 0.072 & 1 & & & \\
\hline & 0.000 & 0.000 & 0.072 & 0.000 & 0.000 & 0.181 & 0.148 & 0.000 & 0.000 & 0.000 & 0.382 & & & & \\
\hline
\end{tabular}


Table 8. Contd.

\begin{tabular}{|c|c|c|c|c|c|c|c|c|c|c|c|c|c|c|}
\hline \multirow{2}{*}{$\mathrm{Ca}^{2+}+\mathrm{Mg}^{2+}$} & $0.814^{* *}$ & $0.766^{\star *}$ & $0.984^{* *}$ & -0.155 & 0.138 & $0.916^{\star *}$ & $0.555^{\star *}$ & $0.431^{* *}$ & $0.665^{\star *}$ & $0.578^{* *}$ & $0.554^{\star *}$ & -0.141 & \multicolumn{2}{|l|}{1} \\
\hline & 0.000 & 0.000 & 0.000 & 0.058 & 0.093 & 0.000 & 0.000 & 0.000 & 0.000 & 0.000 & 0.000 & 0.085 & & \\
\hline $\mathrm{Ca}^{2+}+\mathrm{Mg}^{2+} /$ & $0.178^{*}$ & 0.139 & $0.587^{* *}$ & $-0.633^{* *}$ & $-0.302^{* *}$ & $0.549^{* *}$ & $0.327^{* *}$ & 0.041 & 0.132 & 0.060 & $0.233^{* *}$ & $-0.623^{\star *}$ & $0.597^{* *}$ & 1 \\
\hline $\mathrm{Na}^{+}+\mathrm{K}^{+}$ & 0.030 & 0.090 & 0.000 & 0.000 & 0.000 & 0.000 & 0.000 & 0.621 & 0.107 & 0.468 & 0.004 & 0.000 & 0.000 & \\
\hline
\end{tabular}

$\mathrm{N}=150$. ${ }^{*}$, Significant at 0.01 level; *, significant at 0.05 level.

Table 9. Multiple linear regression models for selected groundwater quality parameters.

\begin{tabular}{|c|c|c|c|c|c|c|c|c|c|}
\hline \multirow{2}{*}{$\begin{array}{l}\begin{array}{l}\text { Dependent } \\
\text { variable }\left[\mathbf{R}^{2}\right]\end{array} \\
\text { EC [0.999] }\end{array}$} & \multirow{2}{*}{$\begin{array}{c}\begin{array}{c}\text { Constant } \\
\text { for model }\end{array} \\
{[-4.12]} \\
{[5.359]}\end{array}$} & \multicolumn{7}{|c|}{ Significant $5 \%$ level regression coefficients for independent variables [std. error of regression coefficients] } & \multirow{2}{*}{$\begin{array}{c}\begin{array}{c}\text { Std. error for } \\
\text { regression model }\end{array} \\
87.149\end{array}$} \\
\hline & & $\begin{array}{l}2.83 \mathrm{Cl}^{-} \\
{[0.017]}\end{array}$ & $\begin{array}{c}1.63 \mathrm{HCO}_{3}^{-} \\
{[0.019]}\end{array}$ & $\begin{array}{c}1.625 \mathrm{NO}_{3}^{-} \\
{[0.015]}\end{array}$ & $\begin{array}{c}2.085 \mathrm{SO}_{4}^{2-} \\
{[0.058]}\end{array}$ & & & & \\
\hline $\mathrm{HCO}_{3}^{-}[0.717]$ & $\begin{array}{c}55.029 \\
{[17.486]}\end{array}$ & $\begin{array}{c}0.988 \mathrm{Ca}^{2+} \\
{[0.113]}\end{array}$ & $\begin{array}{c}2.968 \mathrm{Mg}^{2+} \\
{[0.266]}\end{array}$ & $\begin{array}{c}1.012 \mathrm{Na}^{+} \\
{[0.158]}\end{array}$ & $\begin{array}{c}7.406 \mathrm{~K}^{+} \\
{[1.836]}\end{array}$ & $\begin{array}{c}-0.973 \mathrm{Cl}^{-} \\
{[0.087]}\end{array}$ & $\begin{array}{c}-0.982 \mathrm{NO}_{3}^{-} \\
{[0.009]}\end{array}$ & $\begin{array}{c}0.281 \mathrm{SO}_{4}{ }^{2-} \\
{[0.184]}\end{array}$ & 52.253 \\
\hline $\mathrm{Cl}^{-}[0.892]$ & $\begin{array}{l}-14.490 \\
{[11.253]}\end{array}$ & $\begin{array}{c}2.737 \mathrm{Mg}^{2+} \\
{[0.118]}\end{array}$ & $\begin{array}{c}1.193 \mathrm{Na}^{+} \\
{[0.064]}\end{array}$ & $\begin{array}{c}0.955 \mathrm{Ca}^{2+} \\
{[0.059]}\end{array}$ & $\begin{array}{c}-0.461 \mathrm{HCO}_{3}^{-} \\
{[0.041]}\end{array}$ & $\begin{array}{c}-0.099 \mathrm{SO}_{4}{ }^{2-} \\
{[0.131]}\end{array}$ & & & 36.913 \\
\hline $\mathrm{NO}_{3}^{-}[0.709]$ & $\begin{array}{l}-35.120 \\
{[16.545]}\end{array}$ & $\begin{array}{c}0.204 \mathrm{Ca}^{2+} \\
{[0.212]}\end{array}$ & $\begin{array}{c}1.354 \mathrm{Na}^{+} \\
{[0.131]}\end{array}$ & $\begin{array}{c}1.814 \mathrm{Ca}^{2+}+\mathrm{Mg}^{2+} \\
{[0.263]}\end{array}$ & $\begin{array}{c}-0.723 \mathrm{Cl}^{-} \\
{[0.089]}\end{array}$ & $\begin{array}{c}-1.531 \mathrm{SO}_{4}{ }^{2-} \\
{[0.192]}\end{array}$ & & & 54.402 \\
\hline $\mathrm{SO}_{4}{ }^{2-}[0.692]$ & $\begin{array}{l}16.924 \\
{[6.518]}\end{array}$ & $\begin{array}{c}0.40 \mathrm{Ca}^{2+} \\
{[0.042]}\end{array}$ & $\begin{array}{c}0.363 \mathrm{Mg}^{2+} \\
{[0.064]}\end{array}$ & $\begin{array}{c}0.328 \mathrm{Na}^{+} \\
{[0.032]}\end{array}$ & $\begin{array}{c}0.035 \mathrm{HCO}_{3}^{-} \\
{[0.024]}\end{array}$ & $\begin{array}{c}-0.127 \mathrm{NO}_{3}^{-} \\
{[0.026]}\end{array}$ & & & 21.833 \\
\hline $\begin{array}{l}\mathrm{C} \mathrm{a}^{2+}+\mathrm{Mg}^{2+} \\
{[0.977]}\end{array}$ & $\begin{array}{c}2.529 \\
{[3.727]}\end{array}$ & $\begin{array}{c}0.235 \mathrm{HCO}_{3}^{-} \\
{[0.013]}\end{array}$ & $\begin{array}{l}0.42 \mathrm{Cl}^{-} \\
{[0.012]}\end{array}$ & $\begin{array}{c}0.352 \mathrm{NO}_{3}^{-} \\
{[0.010]}\end{array}$ & $\begin{array}{c}0.448 \mathrm{SO}_{4}^{2-} \\
{[0.040]}\end{array}$ & $\begin{array}{c}-0.724 \mathrm{Na}^{+} \\
{[0.017]}\end{array}$ & & & 12.217 \\
\hline $\begin{array}{l}\mathrm{Na}^{+}+\mathrm{K}^{+} \\
{[0.942]}\end{array}$ & $\begin{array}{c}2.824 \\
{[5.046]}\end{array}$ & $\begin{array}{c}0.328 \mathrm{HCO}_{3}^{-} \\
{[0.018]}\end{array}$ & $\begin{array}{c}0.571 \mathrm{Cl}^{-} \\
{[0.019]} \\
\end{array}$ & $\begin{array}{c}0.465 \mathrm{NO}_{3}^{-} \\
{[0.018]}\end{array}$ & $\begin{array}{c}0.618 \mathrm{SO}_{4}{ }^{2-} \\
{[0.054]}\end{array}$ & $\begin{array}{c}-1.321 \mathrm{Ca}^{2+}+\mathrm{Mg}^{2+} \\
{[0.031]}\end{array}$ & & & 16.631 \\
\hline
\end{tabular}

$\mathrm{N}=150$. 
Table 10. Individual contributions of various independent chemical variables to predict chemical water quality parameters.

\begin{tabular}{lcccccccccc}
\hline $\begin{array}{l}\text { Dependent } \\
\text { variable }\end{array}$ & \multicolumn{8}{c}{ Independent variables } & $\begin{array}{c}\text { Total } \\
\text { variability }\left(\mathbf{R}^{2}\right)\end{array}$ \\
\cline { 2 - 9 } & $\mathbf{N a}^{+}$ & $\mathbf{K}^{+}$ & $\mathbf{C a}^{2+}$ & $\mathbf{M g}^{2+}$ & $\mathbf{H C O}_{3}{ }^{-}$ & $\mathbf{C l}$ & $\mathbf{S O}_{4}{ }^{2-}$ & $\mathbf{N O}_{3}{ }^{2-}$ & $\mathbf{C a}^{2+}+\mathbf{M g}^{2+}$ & 0.999 \\
$\mathrm{EC}$ & & & & & 0.125 & 0.76 & 0.011 & 0.103 & & 0.717 \\
$\mathrm{HCO}_{3}{ }^{-}$ & 0.081 & 0.077 & 0.07 & 0.5 & & 0.11 & 0.328 & & & 0.896 \\
$\mathrm{Cl}^{-}$ & 0.088 & & 0.159 & 0.158 & 0.093 & & 0.398 & & & 0.692 \\
$\mathrm{SO}_{4}{ }^{2-}$ & 0.13 & & 0.11 & 0.074 & 0.328 & & & 0.05 & & 0.709 \\
$\mathrm{NO}_{3}{ }^{-}$ & 0.093 & & 0.45 & & & 0.038 & 0.032 & & 0.096 & 0.942 \\
$\mathrm{Na}^{+}+\mathrm{K}^{+}$ & & & & & 0.128 & 0.192 & 0.193 & 0.196 & 0.234 & 0.977 \\
$\mathrm{Ca}^{2+}+\mathrm{Mg}^{2+}$ & 0.2 & & & & 0.121 & 0.442 & 0.02 & 0.194 & & \\
\hline
\end{tabular}

$\mathrm{N}=150$. All the values are in $\mathrm{mg} / \mathrm{L}$, except $\mathrm{EC}$. Units of $\mathrm{EC}$ are $\mathrm{do} / \mathrm{m}$.

of $\mathrm{Na}^{+}, \mathrm{K}^{+}, \mathrm{Ca}^{2+}, \mathrm{Mg}^{2+}, \mathrm{HCO}_{3}{ }^{-}, \mathrm{Cl}^{-}$and $\mathrm{SO}_{4}{ }^{2-}$, and in case of $\mathrm{SO}_{4}^{-}, 81.7 \%$ of the variability could be ascribed to the combined effect of $\mathrm{Na}^{+}, \mathrm{Ca}^{2+}, \mathrm{Mg}^{2+} \mathrm{CO}_{3}^{-}$, and $\mathrm{SO}_{4}{ }^{2-}$. The regression model of nitrate indicated that a maximum of $70.93 \%$ of the observed variability in nitrate is accounted for by this model. Similarly, $\mathrm{Ca}^{2+}+\mathrm{Mg}^{2+}$ and $\mathrm{Na}^{+}+\mathrm{K}^{+}$ regression model can predict up to 97.7 and $94.2 \%$ variability, respectively.

\section{Conclusion}

Variations noticed in specific water quality substance among the water samples drawn from various bore wells may be attributed to various land use and land cover factors. However, a significant correlation is noticed among many of the tested water quality parameters. The correlation between EC and other water quality parameters is significantly positive. $99.9 \%$ of the variability in EC could be ascribed to the comb ined effect of $\mathrm{Cl}-\mathrm{HCO} 3-, \mathrm{NO} 3-$ and SO42-. The multiple regression model can predict groundwater quality parameters with $5 \%$ level of significance.

The groundwater was classified as very hard and saline. Presence of high chlorides and nitrates concentration indicated potential influence of sewage pollution owing to poor drainage and solid waste disposal system in the city. Fluoride values were high in few samples. Many samples were not fit for drinking purpose. It is suggested to treat groundwater before drinking and potable uses. Suitable strategies to groundwater recharge, controlled groundwater usage, measures to reduce ground water pollution and awareness of the importance of water quality for private bore well users are recommended.

\section{ACKNOWLEDGEMENTS}

The authors thank authorities of PDA College of Engineering, Gulbarga, for the support provided for this study.

\section{REFERENCES}

Adhikari PP, Chandrasekharan H, Debashis Chakraborty, Bhisam Kumar, Yadav BR (2009). Statistical approaches for hydrogeochemical characterization of groundwater in west Delhi, India. Environ. Monit. Assess. 154:41-52.

APHA (American Public Health Association) (1989). Standard methods for the examination of water and wastewater $\left(17^{\text {th }}\right.$ edn $)$. Washington, DC: APHA.

Davis SN, De Wiest RJ (1966). Hydrogeology. New York: Wiley.

Deepali S, Sapna P, Srivastava VS (2001). Groundwater quality at tribal town; Nandurbar (Maharashtra). Indian J. Environ. Ecoplan. 5(2):475479.

Degaonkar, Chaya K (2003). Evolving a health caring water supply and sanitation system: public private partnerships in developing economy. Proceedings of third international conference on environment and health, Chennai, India, 15-17 December.

Durfor CN, Baker F (1964). Public water supplies of the 100 larger city in the U.S. Geological Survey. Water Supply paper 1812. p. 364.

Freeze RA, Cherry JA (1979). Groundwater, New Jersey: Prentice-Hall. p. 604.

Gulbargacity (2010). Gulbarga City Corporation, official website, www.gulbargacity.gov.in, browsed on $12^{\text {th }}$ March 2010.

Haran $\mathrm{H}$ (2002). Evaluation of drinking water quality at Jalaripeta village of Visakhapatanam district, Andra Pradesh. Nat. Environ. Pollut. Technol. 1(4):407-410.

Hudak PF (2000). Regional trends in nitrate content of Texas groundwater. J. Hydrol. (Amsterdam) 228(1-2):37-47.

ISI (Indian Standards Institution) (1991). Indian standard Specification for drinking water, IS 10500, 1-5.

Jain CK, Kumar CP, Sharma MK (2003). Ground water qualities of

Ghataprabha command Area, Karnataka. Indian J. Environ. Ecoplan.

7(2): 251-262.

Joseph K, Jaiprakash NGB (2000). An Integrated approach for management of total dissolved solids in Hosiery dyeing effluents. J. Indian Assoc. Environ. Manag. 27(3):203-207.

Levallois $\mathrm{P}$, Thériault M, Rouffignat $\mathrm{J}$, Tessie S, Landry R, Ayotte P (1998). Groundwater contamination by nitrates associated with intensive potato culture in Québec. Sci. Total Environ. 217(1-2):91101.

Madhavi A, Prasad R (2003). Effect of industrial effluent on properties of ground water. J. Environ. Biol. 24(2):187-192.

Majagi S, Vijaykumar K, Rajashekhar M (2008). Chemistry of groundwater in Gulbarga district, Karnataka, India, Environmental Monitoring and Assessment. 136(1-3):347-354.

Mohapatra D, Das B, Chakravortty V ( 2001). A correlation study on physicochemical characteristics of ground water in Paradip areas. Pollut. Res. 20(3):01-406.

Nas B, Berktay A (2006). Groundwater contamination by nitrates in the City of Konya, (Turkey): A GIS perspective. J. Environ. Manag. 79(1):30-37.

Patil DB, RajendraTV (2001). Studies on water quality of Gadehiroll 
Lake. Pollut. Res. 20(2):257-259.

Pradeep KN, Jivesh AT, Biranchi ND, Arun NT (2008). Impact of urbanization on the groundwater regime in a fast growing city in central India. Environ. Monit. Assess. 146:339-373.

Rasula G, Rasula M (2001). Groundwater quality monitoring system in zones of infrastructure facilities. Eng. Geol. 60:351-360.

Saleem A, Dandigi MN, Vijaykumar K, Balakrishnan P (2011). Groundwater Quality assessment for an Indian Urban Habitat: A GIS Approach. J. Environ. Sci. Eng. 5(12):1561-1569.

Sangeetha V, Ebanazar J, Freedagana Rani (2000). Water quality of ground water of deven villages around Udayarpalayam, Tamil Nadu. J. Ecotoxicol. Environ. Monitoring, 10(2):147-155.

Sawyer CN, McCarty PL (1967). Chemistry for sanitary engineers $\left(2^{\text {nd }}\right.$ ed.). New York: McGraw-Hill Education.

Seong- Sook P, Soon -oh K, Seong - Taek Y, Gi-Tak C, Soon-Young Y, Seungki K, Young K (2005). Effect of land use on the spatial distribution of trace metals and volatile organic compounds in urban groundwater, Seoul, Korea. Environ. Geol. 48:1116-1131.

Shanthi K, Ramaswamy, Pramalsamy P (2002). Hyderobiological study of Signanallur taluk, at Coimbatore, India. Nature Environ. Pollut. Technol. 1(2):97-101.

Sharma KC, Hassain I, Hussain J, Oijha KG (2001). Ground water quality of an industrial town Bhilwara, Rajasthan. J. Environ. Pollut. 8(1):109-114.

Shivashankara AR, Shivaraja Shankara YM, Hanumanth Rao S, Gopalakrishna, Bhat P (2000). A clinical and biochemical study of chronic Fluoride toxicity in children of Kheru Thanda of Gulbarga district, Karnataka, India. Fluoride 33(2):66-73.

Sivakumar R, Mohanraja R, Azeez PA (2000). Physico-chemical analysis of high altitude water source of Ooty, South India. Pollution Res. 19(1):143-146.

Subba Rao N, Gurunadhi VVS, Guptha CP (1998). Ground water pollution due to discharge of industrial effluents in Venkatapuram area. Visakhapatanam, A.P. India. Environ. Geol. 33(4):289-294.
Subba Rao N (2008). Factors controlling the salinity in groundwater in parts of Guntur district, Andhra Pradesh, India. Environ. Monit. Assess 138:327-341.

Subba Rao N (2009). Fluoride in groundwater, Varaha river Basin, Vishakapatnam district, Andhra Pradesh, India. Environ. Monit. Assess 152:47-60.

Subhadra Devi G, Barbaddha SB, Hazel D, Dolly C (2003). Physicochemical characteristics of drinking water at Velsao Goa. J. Environ. Monit. 13: 203-209.

The Hindu (2011), Defluoridation plant opened at Gulbarga, June 19, available online http://www.thehindu.com/news/cities/Mangalore/article2117823.ece.

Todd K (2007). Groundwater Hydrology, John Wiley sons, New Delhi.

WHO (World Health Organization) (1985). Health hazards from nitrates in drinking water. WHO, Regional Office for Europe.

WHO (World Health Organization), (1993). Guidelines for drinking water quality, $2^{\text {nd }}$ edition. Vols. 1 Geneva: WHO. 